\title{
Review Article \\ Rise of Clinical Trials Industry in India: An Analysis
}

\author{
Vikas Bajpai \\ Centre for Social Medicine and Community Health, Jawaharlal Nehru University, New Delhi 110067, India \\ Correspondence should be addressed to Vikas Bajpai; drvikasbajpai@gmail.com
}

Received 10 April 2013; Accepted 19 May 2013

Academic Editors: S. M. Pezzotto, M. San Sebastian, and E. J. Simoes

Copyright (C) 2013 Vikas Bajpai. This is an open access article distributed under the Creative Commons Attribution License, which permits unrestricted use, distribution, and reproduction in any medium, provided the original work is properly cited.

\begin{abstract}
Clinical trials industry has seen a phenomenal increase in last ten years or so, and India has emerged as one of the foremost global destinations for clinical trials. Changed intellectual property regimen after WTO has been the prime mover of the phenomenon, and maximizing profits rather than serving any altruistic motives forms the main ideological underpinning of the rise of clinical trial industry in India. The paper examines the ideological underpinnings of the rise of clinical trials industry in the country in detail and how the ruling classes of India have tried to capitalize on this as a great economic opportunity. In the process the interests of India's poor have been the main casualty.
\end{abstract}

\section{Introduction}

There is a huge volume of literature available from across the world and from within the country that has commented on the phenomenal growth of the clinical trials industry, especially in the developing world. The available literature, at least from India, can be broadly categorized in two groupsone is those writings that have given greater play to societal concerns over the growth of clinical trials industry and the malpractices that it has engendered in the name of clinical research [1-6] and in the second group are the writings that have argued in favor of the growth of clinical trials industry as an economic opportunity as being crucial to the development of clinical research in the country and as such have deliberated on the ways and means to take best advantage of the opportunity [7-12]. This kind of an either "All Black" or "All White" conceptualization of the phenomenon tends to skirt aside the complexity of the issues at hand. For example, for all said and done, clinical trials remain central to "new drug development" and for this single reason there remains a need to develop an understanding of how to "get things right," and to know the right way of doing things we ought to know "what precisely is wrong" with the clinical trials industry in India in the present form, rather than just elucidating the symptoms of the underlying pathology which come forth in the form of all the wrong reasons for which clinical trials have been in news in India.
In the following passages we shall make an attempt to develop a reasoned understanding of the phenomenon of clinical trials as is unfolding in India such that the laity and the healthcare professionals can both become informed participants in the evolving debate over the growing clinical trials industry in the country. Even though it may appear unnecessary for those already having an idea of how new treatments are developed and tested, it would still be a good idea to briefly touch upon the basics for the benefit of the laity who invariably are the end consumers of these treatments.

\section{Some Essential Fundamentals of Clinical Trials?}

Any new drug, treatment device, or treatment regimen that is developed ought to not just be effective for treating the given disease condition but also safe for human use. The safety and the efficacy of all new treatments is judged through "clinical trials." Since clinical trials are a method of answering unanswered questions regarding new treatments (drugs or devices) or treatment regimen, these are "research studies" that are meant to follow strict scientific standards to ensure patient safety and produce reliable study results [13].

There are the following four types of clinical trials.

Phase 1 Trials. These are carried out in a small group of healthy volunteers to test for the safe dose 
for the drug, its side effects, and pharmacokinetics (absorption, distribution within and excretion from the body).

Phase 2 Trials. They are conducted to test the efficacy of a drug against the specific disease condition, to gather further information on the adverse effects, or to test the dose of maximum efficacy.

Phase 3 Trials. These are much larger trials involving thousands of patients possibly at multiple treatment sites (hospitals). Such trials may test a different route of administration, different dose of the standard drug against the standard regimen, or they may test a new drug against the standard treatment for a given condition.

Phase 4 Trials/Postmarketing Trials. These are conducted upon the drug having been found effective and after it is licensed for a given clinical condition. The usual objectives are to find out long-term risks or benefits of the drug, to find new clinical indications of the same drug, or to obtain additional information on its side effects and safety.

Alternatively, phase 4 trials may simply be an excuse for the companies to finance the doctors to put more and more patients on their already approved drugs rather than subserve any scientific purpose [14, page 30].

We can see thus that clinical trials are of cardinal importance in the development of a new drug. So we may put it this way-"clinical trials are a necessary evil in so far as some people have to voluntarily submit themselves to experimentation if mankind were to avail of newer treatments" of administration or a different dose of the standard drug against the standard regimen, or they may test a new drug against the standard treatment followed for a given condition.

\subsection{The Linkage between Clinical Trials and the Anxiety for} Profits. It is difficult to maintain secrecy about a new molecule once its clinical testing begins; hence, drug companies acquire patents on a new molecule before this phase of a new drug development. This protects their exclusive rights over the molecule during the clinical testing period. The duration of the patent granted on a new molecule is for a period of 20 years; but before the company can get the license to commercially exploit a new drug the molecule has to complete the phase of clinical trials to prove its efficacy. It takes anywhere between 2 and 10 years to complete the clinical testing phase of drug development [15]. This means that of the total duration of 20 years for a patent, a substantial period may actually be lost in clinical trials, thus reducing the duration within which the company can make its profits from the molecule without facing any competition. Naturally then the companies are terribly anxious to get the clinical trials out of the way as early as possible to get the drug on the market.

\section{Clinical Trials and the Entry of the CROs}

Traditionally speaking until the post-WTO period clinical trials had largely been conducted in the developed countries of the West which have been the centers of the big multinational pharmaceutical companies, with the maximum numbers being conducted in the United States. The phenomenon of clinical trials and the manner of their conduct has undergone a sea change over the decades. To begin with clinical trials were mainly based in academic medical institutions with their faculty being the clinical researchers; however, with the growth of the drug industry and a larger number of new molecules being discovered need arose to recruit an ever increasing number of patients of a wider variety of diseases to test these molecules. Academic medical institutions alone proved insufficient to cater to this need. Additionally, as the drug companies do not have a direct access to patients, nor do they employ physicians who would directly recruit patients in the trials, there also arose the need for specialized organizations which could perform these tasks for the drug industry. These specialized organizations that arose to fill the void were known as the CROs (Clinical/Contract Research Organizations) [16, pages 21-36].

Limited availability of suitable patients is the biggest constraint in getting a new drug to the market and this is where the CROs pitch in with their entrepreneurial effort. As it originated in the West, a wide array of methods are deployed to recruit trial subjects-advertisements on health related websites, television, radio, and newspapers; individual postings, posters, and flyers distributed in communities and advocacy groups to solicit patients of particular disease. Not infrequently such solicitations are decked up as public service announcements and patients who are recruited are usually paid for their participation in the trial [14, page 30].

However, payments to the patients are far too overshadowed by the pecuniary incentives meant for doctors party to the trials. Just how large these sums can be is shown by a report of the inspector general of the Department of Health and Human Services of the US government. According to this report published in the year 2000 doctors were paid as much as $\$ 12,000$ per patient recruited to the trial and an extra $\$ 30,000$ on the enrollment of sixth patient [17, page 17]. With the inducements being rewarding enough, would it be surprising that the doctor decides preemptor ally that the next patient to come has the disease for which the drug is being tested-say for example, in case of an antidepressant drug? Needless to say that such practice renders the trials results unreliable.

The harmonization of patent laws in the post-WTO scenario has seen a steady drift of clinical trials to many developing countries, India being one of their chief recipients. There has been a resultant growth of CROs in the country and pretty much the same practices that constitute the pantheon of business practices of CROs in the West are being adopted in India as well. The only difference is that the patients here could be far less empowered to ensure that their interests are well taken care of; they invariably are far poorer than trial subjects in the West which renders them much too vulnerable to the CROs/drug company's mechanizations. The following report on patient recruitment for drug trials posted on NBCNews.com only illustrates this too well.

Talking of the agent who has been in the business of recruiting patients for different companies/labs the report 
states that the agent is paid $\$ 12$ for each recruit that he brings for the three Indian labs that he works for, and in a region where an average worker earns just 50 cents, this is a princely sum. Depending on the length of the study the total income of the recruited patients can be as much as $\$ 400-$ a dream sum for a poor Indian by any standard. Moreover, it was reported that people often get enrolled in more than one study at a time. The agent himself feels of his work as follows: "I do not feel guilt... I believe conducting these studies is a humanitarian effort. So many people benefit from (the) advancement of medicine." The desperate poverty of the recruits obliges them to disregard the potential risks of the experimental treatment that they are required to undergo. Sickness among the trial participants is not infrequent. "There are many instances where there are swellings in the limbs, loss of eyesight," and even deaths being reported with fair regularly [18].

Dr. Chandra Gulhati, editor of the "Monthly Index of Medical Specialties," is reported to have said that "Unlike the Western countries where there is an audit of each death during [a] clinical trial, we do not have a system like that at all" [18]. This yearlong investigation raises some important questions on the laxity of regulatory oversight of clinical trials in India, the integrity of the CROs, and the inviolability of the data generated through these trials and serves as a stimulating starter to the main course discussion on these aspects later in the paper.

\section{The Quantum and Drivers of the Growth of Clinical Trials Industry}

The foregoing sections equip us with the fundamentals to comprehend the phenomenon of the growth of the "Clinical Trial Industry." In this section we shall attempt to fathom the quantitative dimensions of this phenomenon and the factors that have driven this growth with a view to understand the ideological underpinnings of the phenomenon.

Figures 1,2, and 3 give a very clear idea of the phenomenal rise of clinical trials in India and particularly the fact that clinical trials industry arrived in its own since the year 2005. In terms of financial turnover, between 2003 and 2010 the industry has grown by more than 100 times at the rate of 1414 percent annually. Findings of Figure 1 to Figure 3 are quite in line with the findings of a 2005 survey of the leading $\mathrm{R} \& \mathrm{D}$ investor firms in the world (Figure 4) conducted by UNCTAD (United Nations Conference on Trade and Development) that predicted India to emerge as the third most favored country for R \& D related investments globally after China and the United States [19]. The final results, however, seem to have even bettered the earlier predictions. In 2009 India was the most favored destination for creation of new jobs in R \& D, ahead of United States and China which were ranked second and third [20].

4.1. What Really Has Fuelled This Growth? India was party to the Uruguay round of GATT (General Agreement on Trade and Tariffs) negotiations which culminated in an agreement between 75 countries and the European Community leading to the formation of WTO (World Trade Organization) in

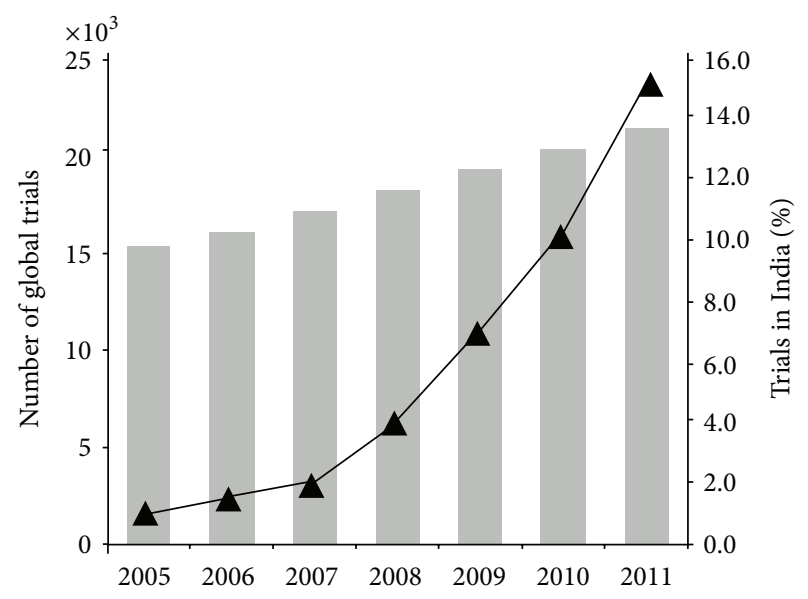

FIgURE 1: Number of global trials and the proportion in India. Source: The Boston Consulting Group and Business Communications Company data quoted in Mishra [21].

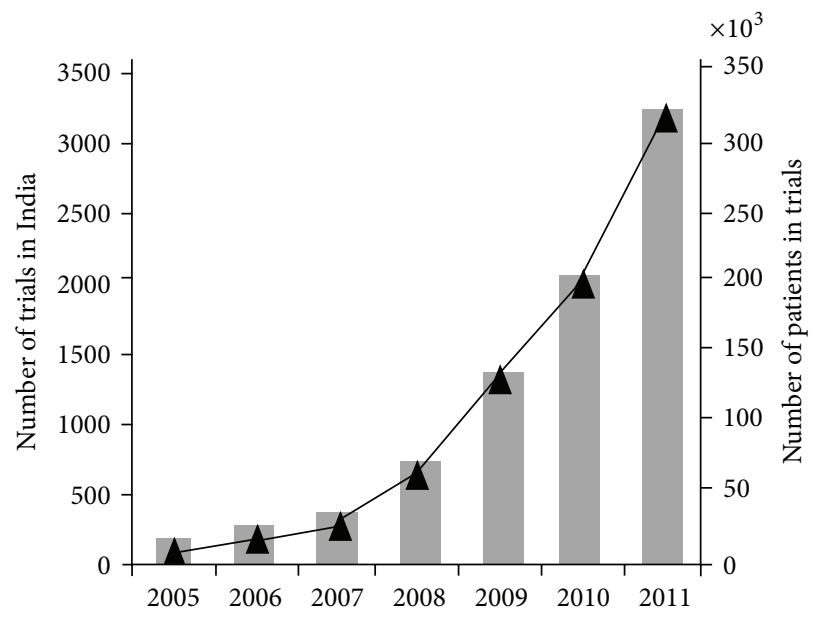

Figure 2: Number of trials and patients in India. The Boston Consulting Group and Business Communications Company data quoted in Mishra [21].

1995. WTO obliged the signatory countries to harmonize their intellectual property rights with the provisions of “TRIPS" (Trade Related Intellectual Property Rights). With respect to pharmaceutical products this meant that the countries had to recognize product patents protection [2325]. Article 33 of the agreement on "Intellectual Property Rights" provided for patent protection for a period of 20 years from the period of filing of the patent [23-25]. With the professed objective of enabling "them to create a sound and viable technological base" the least developed countries were granted a period of 10 years from 1995 to harmonize their patent regimens with TRIPS obligations. The 2001 Doha round of negotiations on TRIPS and Public Health further extended this period up to 2016 [23-25].

India became fully TRIPS compliant from January 2005 onwards, formally recognizing product patents. Product patents were introduced for all industrial sectors under the "Patents (Amendment) Act 2005." The earlier "Indian Patent 


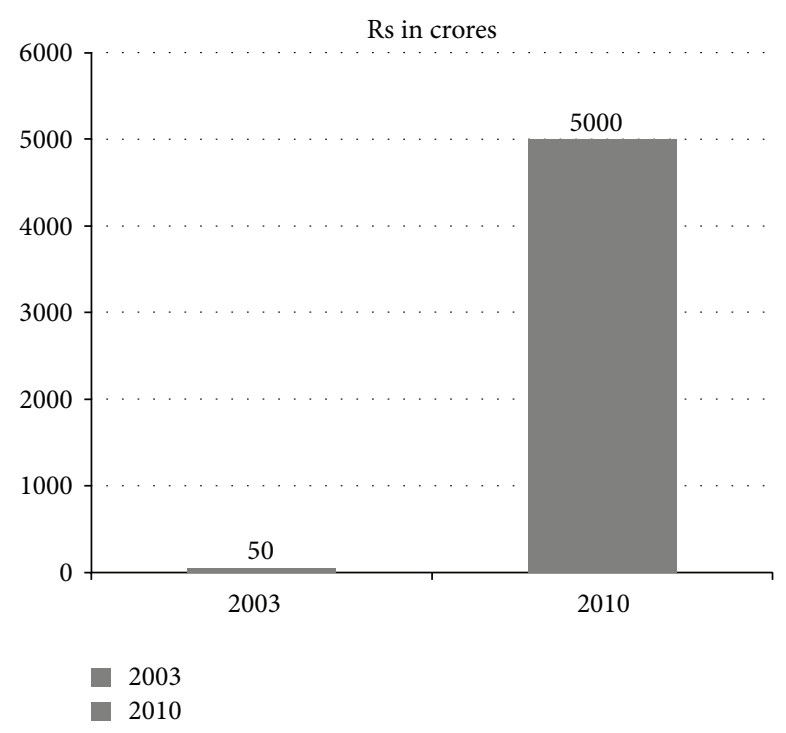

FIgURE 3: Financial growth of clinical trials industry in India. Source: Vasireddi [22].

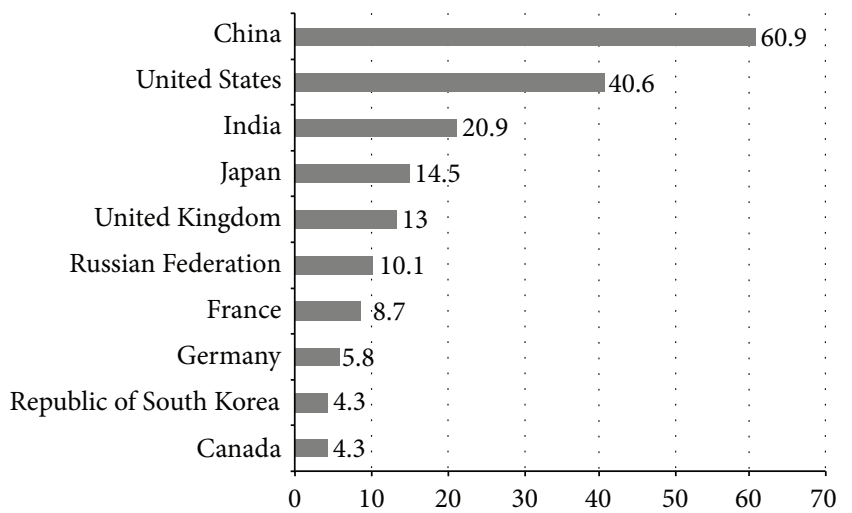

FIgURE 4: Most attractive locations for future foreign R \& D in UNCTAD survey, 2005-2009 (percent of responses).

Act, 1970" guaranteed only process patent, meaning thereby that the same drug that may have been discovered in the West could be made by an Indian company without fear of patent infringement through an alternative process for which it could file a patent [26].

Along with this change over to product patents in January 2005, India also amended the schedule Y of the "Drugs and Cosmetics Rules" to allow drug trials without a phase lag in the country, that is, as against the earlier requirement of allowing say a phase 2 clinical trial in India only if a phase 3 trial of the drug had been completed outside; the new rule permitted conducting the concurrent trials of the same phase in India. The earlier rule that was meant to protect Indian subjects from being treated as guinea pigs is said to have been upturned under the impact of concerted lobbying by the pharmaceutical companies and the CROs [27].

The project is yet an ongoing one. Outlining the longterm goals of the government of India the former DCGI (Drug Controller General of India), Dr. Surender Singh even said that the government even intended to permit the phase 0 and phase 1 trials of drugs discovered outside the country and that there was even a proposal for setting up "clinical trials export promotion council" in the country [28].

This chronology of events presented earlier is nothing new and indeed can be found in most of the articles written on the subject. We have reproduced these here to highlight just one fact-that "Clinical Trials are an Out and Out Commercial Venture" and "How Profoundly Devoid of any Concern for Human Welfare the Whole Process Is."

Drug discovery and its clinical development through clinical trials is to facilitate new treatments for diseases afflicting mankind and thereby to ensure and further human welfare. However, from multilateral agreements on intellectual property to amendments in the national laws the primary concern is first to secure "exclusive rights to profit from innovations" for the corporations, to dominate markets for drugs, and to make the R \& D capabilities of the developing countries subservient to the economic interests of the western multinationals rather than harnessing them for finding solutions to the health needs of indigenous population-of course with active collaboration of the rulers of these countries. The laws that were designed to protect the poor in the developing countries from the experimental designs originating in the west come to be treated as irritants and road blocks in the development of "R \& D," "science," and "economy" and, hence, ought to be repealed. The "economic expedient" thus overpowers the "human well-being."

Human welfare is rendered incidental, incidental to profits-newer drugs shall be discovered and sold only if they are profitable; innovations shall be incidental to pursuit of further profits and not "human welfare" per se. One may argue that what is the harm if newer drugs for human needs keep coming through a process that also ensures profits for the drug companies; after all do not the companies invest millions of dollars into creating drugs that we all need, and do not they need to recover the money to remain economically viable? It may have been fine if the things were just that, but we may postpone knowing the truth for a bit later in the paper.

Meanwhile, one issue can be settled here for sureneither the growth of clinical trial industry in India has been in pursuance of the health needs of the people of the country nor is the government (let alone the private players) keenly pursuing it for anything other than as a great economic opportunity.

Additionally, the new patent regimen ensures that the so called advancement in "science" and "knowledge production" that is expected to come about as a result of the outsourcing of R \& D to India shall be tightly controlled and appropriated by the western pharmaceutical transnationals.

4.2. Hard Selling of Clinical Trials. We have already noted that "economic expedient" more than "human welfare" is what has shaped Indian government's policy on clinical trials. What is, however, disgusting is the manner in which the misery of Indian people has been leveraged to sell India as the destination of choice for outsourcing clinical trials. Table 1 gives the selling points for why the clinical trials should be outsourced to India, as enumerated by the former DCGI. 
TABLE 1: Resource advantages as destination for clinical trials.

(i) Large no. of specialists in different therapy segments

(ii) Medical training in English

Investigators

(iii) 600,000 English speaking physicians

(iv) PG training from Europe/US

(v) Treatment protocols in line with west

(vi) Large no. of ICH/GCP complaint investigators/sites

(i) Large, diverse, therapy-naïve

(ii) Advantage of having 6 out of 7 genetic varieties

Patient population (iii) Large pt. pool in acute/chronic disease segment

(iv) Increasing no. of pts in life style disorders segment, HIV, oncology

(i) Over 200 medical colleges

(ii) Over 22,000 graduates per year

(iii) 15,622 hosp., 903,952 hosp. beds $>75 \%$

in urban area

(iv) 14000 diagnostic labs

Clinical research

infrastructure

(v) 700,000 scientists and engineering graduates/year

(vi) World class medical/lab facilities at secondary/tertiary care centers

(vii) Skilled computer savvy biomedical work force

\begin{tabular}{ll}
\hline IT support & $\begin{array}{l}\text { (i) Highly developed IT/ITES } \\
\text { (ii) Motivated and committed personnel }\end{array}$ \\
\hline \multirow{3}{*}{ Connectivity } & (i) High quality digital connectivity \\
& (ii) Excellent air/surface transport facilities \\
& across country
\end{tabular}

Source: Surender Singh [29].

The resource advantages mentioned in Table 1 are the standard selling points that are mentioned in the large number of Indian articles on the subject; hence, there is nothing new about them. The reason for our mentioning them here is to draw out two distinct observations:

(i) the elitist nature of our medical education system and health services,

(ii) the manner in which Indian people have been paraded as ideal subjects for clinical studies conceptualized in the West to serve the economic and even the therapeutic needs primarily of people in the developed world.

Apart from these two, the DCGI has been making great promises of "fixed timelines of 2-3 weeks" for approval of new applications for conducting trials through "single window clearance" [29].

\subsubsection{Elitist Nature of Medical Education and Health Services.} A medical education system groomed on English language as its medium of instruction not only debars working masses of India from being able to master medical science to directly take charge of their health needs, but it also aligns the value system and philosophical outlook of medical practice in tune with those prevalent in the developed countries of the West. Increasingly, especially during the period of neoliberal economic reforms, health services system in India has evolved along the lines of entrepreneurial medicine practiced in the United States rather than healthcare as a welfare function of state as practiced in Western Europe. Profit making through provision of healthcare and personal aggrandizement through medical practice as the primary motive have not only become increasingly legitimized but even desirable. Associated with this has been and increasing affiliation among medical professionals for high end technologies irrespective of their desirability in the overall social, political, economic, and cultural context of healthcare in developing countries like India. This also undervalues the indigenous knowledge systems in health and more context specific solutions for local health needs of the people.

All of this has a direct impact on the way medical research is carried out-what health problems are chosen for research, for example, those affecting the affluent more than those afflicting the poor; what possible solutions are privileged for research studies, for example, curative measures over preventive and promotive measures; how the researchers conceptualize their research questions, for example, greater emphasis on the biomedical aspects of disease rather than its social and economic roots and last but not the least a desire for material gratification for his/her contribution and easy culpability in the unethical practices.

So next time when compliance with ICH (International Committee on Homogenization) and GCP (Good Clinical Practice) is mentioned, it should make us think whether such criterion should be context specific? They are nonetheless specific to the context of the developed countries of the West.

4.2.2. Parading Indians as Appealing Trial Subjects. "Large, diverse, therapy-naïve," and "Large patient pool in acute/ chronic disease" have become the catch phrases to promote the clinical trials. Even at the cost of stating the obvious let us demystify the terms "therapy-naïve" and "large patient pool" - while the former simply refers to those who are not able to access treatment, the later implies that there is a high incidence and prevalence of all kinds of diseasesacute and chronic. These are facts which should ideally shame the collective conscience of the country but have most unfortunately been paraded as a virtue by many, among them the highest official of the government of India who is meant to supervise the clinical trials-the DCGI included.

4.2.3. Fixed Timeline Single Window Clearance. The following are some of the findings of a 2007 report- "The Food and Drug Administration's Oversight of Clinical Trials"-of the OIG (Office of the Inspector General) of "Department of Health and Human Services," Government of United States [30].

(i) Due to nonmaintenance of a clinical trials registry FDA is unable to identify all ongoing clinical trials and their associated trial sites, neither does it have full record of IRBs (Institutional Regulatory Bodies). These deficiencies have resulted in its inability to fully track bioresearch monitoring inspections. 
(ii) "FDA relies on voluntary compliance to correct violations of regulatory significance." Additionally, "FDA guidance and regulations do not reflect current clinical trials practices."

(iii) During financial year 2000 to 2005, FDA could inspect only about 1 percent of the clinical trial sites.

We can add to these the frequent allegations of industry influence over FDA [31, 32].

This then is the scenario regarding the regulation of clinical trials in the country which still hosts the largest number of clinical trials in the world, which generally has high standards of living, where people are much better informed of their rights, and where law suits for damages due to wrong treatment are very well known, and where there are formal laws regarding compensation to victims in case things go wrong in a clinical trial.

Interestingly, despite such glaring shortcomings in FDA's oversight, it is claimed that "An important force that is moving clinical trials to developing countries is the increasingly bureaucratic and expensive regulatory environment in many wealthy countries. Regulations governing the conduct of clinical research have become more and more complex, placing a greater burden on investigators in terms of compliance, documentation, and training" [33]. Indeed if the industry and its acolytes could have their way, they would let the markets alone to decide on the safety and efficacy of new drugs and medical devices.

In this context it should send our alarm bells ringing loud when the government talks of giving "fast track single window" clearance to new clinical trial applications-that is in a country where the phenomenon of clinical trials has come into its own only since 2005; where regulatory mechanisms are as yet weak and are still evolving; where a large number of people live in conditions of abject poverty and are either illiterate or barely literate with little information of their rights, especially as clinical trial subjects; where libel suits on account of medical malpractice is still a rarity; and where there are no laws for compensations to victims of wrongfully done clinical trials, but only some guidelines.

On top of all this the singular force setting the pace for clinical trials is the "economic incentive." As regards regulatory environment hopes are expressed in academic journals that "Economic interests"-please note, it is not patient's interests- "will encourage India's regulatory authorities to clarify the rules, expand their resources, and improve skill levels" [9]. Things need only be viewed with that much more alarm if the country's principle watch dog over clinical trials-Central Drugs Standard Control Organization (CDSCO) - is indicted for corruption by none other than the "Parliamentary Standing Committee on Health and Family Welfare." In its report on the functioning of CDSCO tabled in the Parliament on May 8, 2012, the Parliamentary panel indicted the DCGI for clearing as many as 31 new drugs between January 2008 and October 2010 without conducting clinical trials to prove their safety and efficacy for Indian patients. The opinions of the so called experts on these drugs were not found to be based on "scientific data" and the report notes- "Many opinions were actually written by the invisible hands of drug manufacturers and experts merely obliged by putting their signature." The conduct of the experts was found to be in violation of the "the Code of Ethics of the Medical Council of India" and deemed fit for punitive action by the MCI [34].

It need only be added here that there is enough evidence available to show that the "invisible hand" of the drug manufacturers is not too infrequently involved even in the writing of the results of clinical trials as well [11, 35-38].

4.2.4. Thumbing the Regulations in the Nose. If one is powerful enough, turning all regulatory provisions on their head is not a big deal as is shown by this enlightening example involving the country's premier medical institute, All India Institute of Medical Sciences (AIIMS) and the principle regulatory body for scientific research in the country ICMR. All India Institute of Medical Sciences (AIIMS), New Delhi, distributed information through the newspapers on success in treating cardiac disease in humans by using stem cell transplants. Attempts at obtaining information on the scientific basis for this therapy did not meet with success. A search failed to turn up publications on experimental studies, animal trials, and phase 1 and 2 clinical trials regarding this study in indexed medical journals prior to the newspaper reports. The research involved the country's most reputed cardiothoracic surgeon and former director of AIIMS. The director-general, ICMR, was quoted thus by The Hindu on April 5, 2005 on this study carried out at AIIMS: "Dr N K Ganguly today said he stood by the authenticity of the work by the Institute (AIIMS)" [39].

However, Dr Vasantha Muthuswamy, ex-senior deputy director-general and head of the basic medical sciences division of ICMR, courageously went on record to state, with reference to these claims: "We are only a block away from AIIMS and we did not know this was happening there. If the nation's premier medical institute did not ask our permission for such therapy, how can we blame private clinics for what they do?" [40]. She was understandably frustrated and voiced her feelings to the journal Nature, referring to the mushrooming of clinics offering stem cell therapy without any evidence that they were following basic ethical guidelines and scientific practice: "We want to promote stemcell technology but not in this scandalous way" [41].

Let alone the private research institutions, corporations, and the CROs, the litany of such examples involving government institutions and bodies is overwhelming [28, 42, 43].

In the context of a scenario where regulatory framework is being put in place more to fulfill the requirements of foreign sponsors than to protect the interests of Indian people, there is every chance that the public servants meant to act as regulators would end up being the servants of the industry. WHO calls this phenomenon "regulatory capture;" that is, the authority is seized by the very interests it is supposed to regulate [44].

\section{Shrouding Greed with Claims of Service to Humanity}

Anything with even a veneer of service to humanity can come in handy to sell it to the people irrespective of its cost. Every new drug (whether a genuinely new one or tweaked 
from an existing one) can be said to have the potential of reducing human suffering and the pharmaceutical companies have been good at using this one aspect to harness more than a fair share of profits. The byline is that "it costs enormous sums to the drug manufacturers to discover new drugs and that the pharmaceutical companies would go broke if they were not to recover their investments; hence the high price of drugs." One time president of "Pharmaceutical Research and Manufacturers of America" (PhRMA), Alan F Holmer said: "Believe me, if we impose price controls on the pharmaceutical industry, and if you reduce the R \& D that this industry is able to provide, it's going to harm my kids and it's going to harm those millions of other Americans who have life threatening conditions" (Alan F. Holmer on National Public Radio, Talk of the Nation, hosted by Juan Williams, January 2, 2001, quoted in Marcia Angell [14, page 40].

Indeed, one of the biggest push factors for trials to shift to countries like India in large numbers has been the huge cost reductions in the clinical development phase of new drugs that these countries offer. In India it could cost up to 50 percent less to conduct clinical trials, due to a conglomeration of reasons, than the cost incurred in either USA or Europe. So, this also becomes the reason for the Indian pharmaceutical industry and CROs to partake in this great humanitarian project and if not justify, to at least "explain away" the associated negative fallout.

In November 2001 a team of economists led by Joseph DiMasi of the Tufts Center for the Study of Drug Development which is largely supported by the pharmaceutical industry came up with an enigmatic figure of $\$ 802$ million as the cost incurred for the development of a new drug [45]. The figure has since been uncritically quoted in the literature and even been inflated further.

The consumer advocacy group "Public Watch" carried out a sophisticated analysis of the R \& D cost incurred per new drug by taking all the new drugs that entered market between 1994 and 2000 and PhRMA's own data on the amount spent on $\mathrm{R} \& \mathrm{D}$ by drug companies. The figure that emerged was about $\$ 100$ million for each drug after deduction of tax [46]. It must further be borne in mind that the declared $\mathrm{R} \& \mathrm{D}$ costs of companies could be greatly hiked by including increasing expenditure incurred by the companies on say Phase IV trials in the name of research but which actually might only be meant to pay the doctors to prescribe a drug to a larger number of patients; that is, a considerable part of marketing expenditure also gets included into R \& D. Additionally, high $\mathrm{R} \& \mathrm{D}$ costs of newer drugs could very well highlight drug industry's inefficiency by failing to get new drugs of value into the market [45].

Last but not the least, the R \& D expenditure of pharmaceutical majors has remained considerably lower than their total marketing expenditure. Table 2 shows the 2001 (the year $\$ 802$ million per new drug figure was released) expenditure on R \& D by US Corporations marketing top 50 drugs meant for older people [47].

It ought to be clear then that when the Western multinational corporations are shifting the clinical part of drug development to countries like India it is not for altruistic reasons, nor is it for their inability to recover their costs incurred in $\mathrm{R} \& \mathrm{D}$ in the Western countries, but because they have been presented by the WTO Patent Regime an opportunity to maximize their profits by using the easy availability of patients from developing countries (difficulty in recruiting large number of patients in the West being the biggest reason for prolonging the clinical development phase and, hence, cutting into the exclusive profits to be made within the duration of patent) to be able to expeditiously complete the clinical trials without fear of losing control over the molecule. These developments obviously have had consequences for $\mathrm{R}$ \& D in India as well about which we shall discuss in a while.

\section{Who Innovates and Who Appropriates, at Whose Cost?}

Before we proceed to the main text of this section some basic facts need be known first. Basic research carried out in the universities and other academic institutions is fundamental to product innovations by industry. With respect to biomedical science this is especially so. Government is the prime funder of basic research in the US [48, 49] while industry primarily funds the applied research [49]. In President Obama's budget request for the financial year 2013, the Department of Health and Human Services, primarily through the National Institutes of Health (NIH), alone accounts for more than 50 percent of federal funding for basic research in the US [50].

Overwhelming bulk of the funding by $\mathrm{NIH}$ is by way of extramural grants to universities and other academic institutions, while about $10 \%$ of it is invested in intramural research conducted by its own scientists. In drug innovation process even though basic research constitutes only 27 of the total expenditure (PhRMA data for US in 1998 and quoted in [51]), it constitutes the foundation upon which further preclinical and clinical development of a drug rests. The new therapeutic molecules developed in the labs doing basic research are picked up by the drug companies for further development into a new drug. Among other factors publically funded basic research carried out by the teaching hospitals and universities has been a major factor in drug innovation in US [48].

Given this context, if there is any one factor that has played a singular role in defining the character of modern pharmaceutical industry in United States then it was the passage of the Bayh-Dole Act of 1980 which redefined the ownership of intellectual property rights in the US Bayh-Dole Act provided for the universities, small businesses, and the not for profit institutions to retain the title to patents issued for discoveries or inventions made by them through research funded through public money ([52], pages 6-9, [53]). Prior to this the government retained ownership over the patents obtained for innovations made using public money $[14,16,52$, 53]. As government used to grant nonexclusive licenses on its patents to one or more drug companies for further development the companies were not interested in licensing in the patents as they wanted exclusive (read monopoly) rights over the drug to be developed from the patented innovation [53]. Nonexclusive licensing meant that two competitors could develop the same drug. As a result it is said that prior to passing of the Bayh-Dole Act in 1980 fewer than 5 percent 
TABLE 2: Financials for US Corporations Marketing the Top 50 Drugs for Seniors, 2001.

\begin{tabular}{|c|c|c|c|c|}
\hline \multirow{2}{*}{ Company } & \multirow{2}{*}{$\begin{array}{c}\text { Revenue } \\
\text { (net sales in millions } \\
\text { of dollars) }\end{array}$} & \multicolumn{3}{|c|}{ Percent of revenue allocated to } \\
\hline & & $\begin{array}{c}\text { Marketing/ } \\
\text { advertising/administration }\end{array}$ & $\mathrm{R} \& \mathrm{D}$ & $\begin{array}{c}\text { Profit } \\
\text { (not income) }\end{array}$ \\
\hline Merk and Co. Inc & 40,363 & $15 \%$ & $6 \%$ & $17 \%$ \\
\hline Pfizer Inc. & 29,574 & $39 \%$ & $15 \%$ & $13 \%$ \\
\hline Bristol-Meyers Squibb company & 18,216 & $30 \%$ & $11 \%$ & $26 \%$ \\
\hline Pharmacia corporation & 18,144 & $37 \%$ & $15 \%$ & $4 \%$ \\
\hline Abbott laboratories & 13,746 & $21 \%$ & $10 \%$ & $20 \%$ \\
\hline American home products corporation & 13,262 & $38 \%$ & $13 \%$ & $-18 \%$ \\
\hline Eli lilly and Co. & 10,862 & $30 \%$ & $19 \%$ & $28 \%$ \\
\hline Schering-plough corporation & 9,815 & $36 \%$ & $14 \%$ & $25 \%$ \\
\hline Allergan Inc. & 1,563 & $42 \%$ & $13 \%$ & $14 \%$ \\
\hline Total (dollars in millions) & $\$ 166,678$ & $27 \%(\$ 45,413)$ & $11 \%(\$ 19,076)$ & $18 \%(\$ 30,599)$ \\
\hline
\end{tabular}

Source: Families USA (2002): [47].

of the government patents had been used by the industry. It is important to note here that US hardly had any public sector worth a name to be able to capitalize on government held patents.

We need to understand this in more practical termsthe companies wanted monopoly rights over the drugs to be developed by them from government licensed patents such that they could have monopoly pricing over the drugs and monopoly over the profits to be made from a drug for the life of its patent. The Bayh-Dole Act facilitated precisely this. It allowed the universities to hold patent for their innovations made through public funding and sell either their patents or license it exclusively to drug companies for a variety of pay back arrangements. The individual innovator was also entitled to get his share of the booty. The government on its part expected to generate revenues by being able to get higher taxes from the burgeoning profits of the companies [53]. As can be seen from Figures 5 and 6, the Act opened the flood gates to a rush of patents filed by the universities (Figure 5) and through technology transfers by transferring exclusive rights to these patents to different drug companies, a surge in output of new drugs (Figure 6). The rise in the number of patents and new pharmaceutical compounds is particularly sharp after 1980. Since 1980 nearly 2200 new companies were formed based on innovations coming from academic institutions and as of 2005 patents generated in the universities generated $\$ 30$ billion worth of economic activity and 250,00 jobs in US every year. Bayh-Dole Act thus proved to be the proverbial golden goose for the drug industry in the US.

This, however, is not to say that Bayh-Dole was the most desirable thing to happen to the people, particularly the patients, in US Even though it is not our intention here to discuss the Act in any greater detail than what has been necessary, it need be mentioned here that among its various adverse impacts the worst was that it thrust commercial interest in biomedical research at precisely the places where they do not belong - the teaching hospitals and institutions of higher learning.

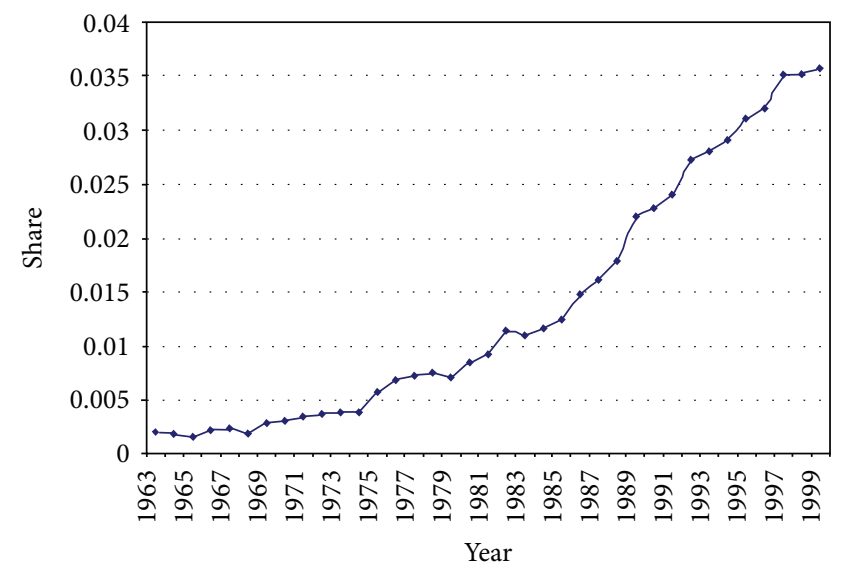

FIGURE 5: Surge in patents granted to research universities over the years. Source: [53].

Drug industry in USA has resisted any government regulations to control the prices of prescription drugs. Industry's argument being "imposition of price controls or price ceilings would decrease profit incentives for researching and developing new medicines and ultimately hurt consumers" (Phrma quoted in [56]). Consequently, "The prices Americans pay for prescription drugs, which are far higher than those paid by citizens of any other developed country, help explain why the pharmaceutical industry is - and has been for years-the most profitable of all businesses in the US" [57].

From the foregoing discussion we can make the following conclusions with reasonable confidence.

(i) Publically funded research has been and continues to be at the base of much of the new drug innovation rather than private enterprise.

(ii) The "new drug innovation" that the drug industry claims to live by might as well not have happened if it did not ensure mega profits to the industry. Industry 


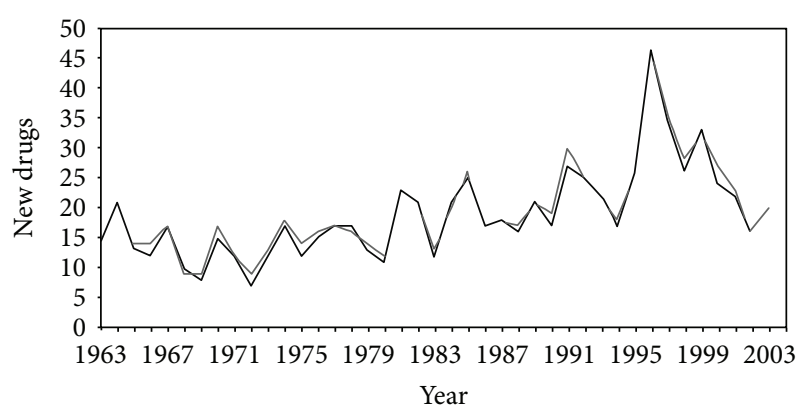

- FDAs NMEs

— Tufts NCEs

Figure 6: NMEs and NCEs by year, 1963-2003. FDA: United States Food and Drug Administration. Tufts: stands for Tufts Centre for Study of Drug Development which is a pharmaceutical industry supported research centre located at Tufts University. NME: New Molecular Entity. A new molecular entity is defined by FDA as a new product containing as its active ingredient a chemical substance marketed for the first time in the United States ([54], quoted in [55]). NCE: New Chemical Entity. The Tufts Centre for Study of Drug Development has defined an alternative to the NMEthe New Chemical Entity. An NCE is defined to be any new molecular compound (excluding diagnostic agents, vaccines, and other biologic compounds) not previously approved for human use by Centre for Drug Evaluation and Research (CDER) which is a division of FDA. New salts, esters, and dosage forms of previously approved compounds are also excluded (Tufts CSDD Glossary, 2004, quoted in [55]). In this figure the difference between NME approval volumes and NCE volumes is accounted for by a small number of molecules which Tufts CSDD considers to be diagnostic (and therefore not an NCE) but are counted as NMEs by the FDA (Di Masi interview, 2004, quoted in [55]). Source: FDA, Parexel Pharmaceutical Industry R \& D Source Book, 2004/2005, as shown in Graham [55].

needed exclusive hold over the new patents to start churning out new drugs.

(iii) The exclusive title to patent of an innovation goes against "free competition"- the much valued spirit of capitalism. If the same molecule were to be clinically developed by more than one company, maybe many more clinical innovations could be made than achieved by just one company. If an exclusive patent to an NME is held by one company, it would tend to make only one clinical innovation from it at a time and make profit from it for 20 years, before tweaking the same molecule to create an almost similar, but technically new molecule to extend the patent life of the molecule.

(iv) The present patent regimen has been specifically designed to ensure that the outcome of the publically funded research continues to be smoothly channeled for raking in private profits by the corporations and their shareholders through monopoly titles to patents.

(v) While the corporations, the researchers, the academic institutions, and even the ruling establishment continue to make fast buck, the actual motive force

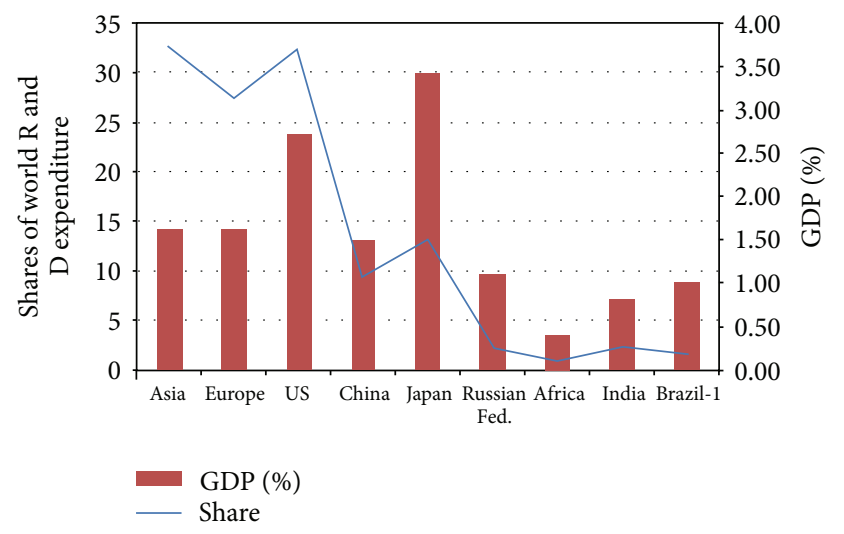

FIGURE 7: R \& D investment as percent of GDP and share of world expenditure, 2007. Source: Kumar and Asheulova [60]. Brazil-1 indicates figures for 2006 .

behind all pharmaceutical research-the patientscontinues to pay the highest price in search for solutions to their misery.

(vi) If the whole system of innovation and drug manufacturing is so organized that the interests of the common patients are privileged over pursuit of mega profits, much greater human welfare can be achieved. Surplus and profits can still be generated but the value system that emphasizes that it is "not only reputable to be wealthy, but something close to virtuous" [52, page 6] would stand to lose.

(vii) Figure 6 shows that the innovation frenzy unleashed by the Bayh-Dole Act already seems to have dried up by 2003 with there being considerably fewer NMEs/ NCEs approved by FDA. Indeed concerns have been expressed regarding the clinical advantage of the new drugs being produced by the industry while it continues to maintain its profit margins through artificially hiked prices [58].

All of the foregoing discussion would perhaps not have been required here from the perspective of the situation in India, if these outcomes were specific only to USA. That, however, is not the case with the beacon light of the Indian policy establishment continuing to shine ever brighter in Washington DC.

6.1. The Situation in India. Inspired by the Bayh-Dole Act, India introduced the "The Protection and the Utilization of the Public Funded Intellectual Property Bill" in the Parliament in 2008. There can indeed be a highly contested debate over the desirability of such a law in the country and indeed eminent opinions have already been expressed on why such a copycat Act may not succeed in the developing countries [59]. However, even if we were to drop all apprehensions regarding the implementation of such an Act in India, would such an Act deliver for India? Figures 7 and 8 show India's contribution to world R \& D.

Let alone a comparison with a super power like US the $\mathrm{R}$ $\&$ D expenditure of India as also the number of its research 


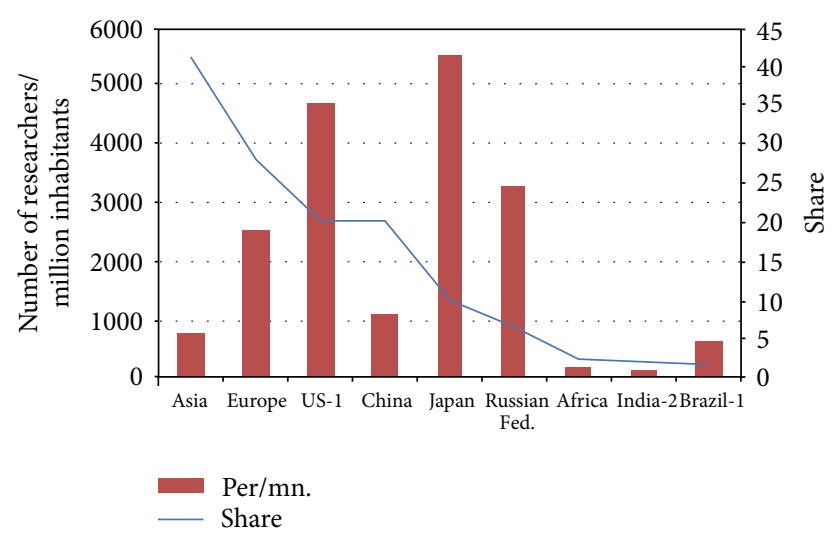

FIGURE 8: Share of world's researchers and researchers per million population, 2007. Source: Kumar and Asheulova [60]. US-1 indicates figures for 2006, Brazil-1 indicates figures for 2006, and India-2 indicates figures for 2005.

personnel is nowhere in comparison with even China, a country which India views as its competitor. We have already seen that USA's leading status in medical research has been fuelled largely by high government funding for universities and other academic institutions. From the circumstances that have already been discussed it comes through that this is not an incidental but a necessary condition for development of science and technology because private sector's spending on $\mathrm{R} \& \mathrm{D}$ is subject to the conditionality of profits.

In India's case the "National Science and Technology Policy" unveiled at the Indian Science Congress in 2003 promised to increase the $S \& \mathrm{~T}$ spending up to 2 percent of GDP by 2007 (end of 10th Plan period). However, in the Science Congress held at Chidambaram in 2007 Prime Minister Manmohan Singh promised the same goal to be achieved by the end of 2012, and in 2012 as a measure of his commitment to science he again extended the target date for the same goal up to end of 12th Plan period in 2017. Government's share of total spending on R \& D dropped from 80 percent in 1990-1991 to 66 percent in 2007-2008 [61]. Further, the Prime Minister hopes to achieve an increase in total R \& D spending by increasing the private sector spending up to 50 percent of the total R \& D spending [62].

6.2. $R$ \& $D$ by Drug Companies in India. Innovations in low knowledge based process chemistry enabled the Indian drug companies to reverse engineer the drugs innovated by the drug companies in the developed countries during the period when Indian law recognized process patents and not the product patents. Resultantly, the Indian drug companies while being strong on manufacturing the generics have managed with very low $\mathrm{R} \& \mathrm{D}$ expenditures compared to international standards [63]. ("A generic drug is a pharmaceutical product, usually intended to be interchangeable with an innovator product, that is manufactured without a license from the innovator company and marketed after the expiry date of the patent or other exclusive rights" (WHO, available from http://www.who.int/trade/glossary/story034/ en/index.html on 24th Mrach 2013.). Under the pre-2005

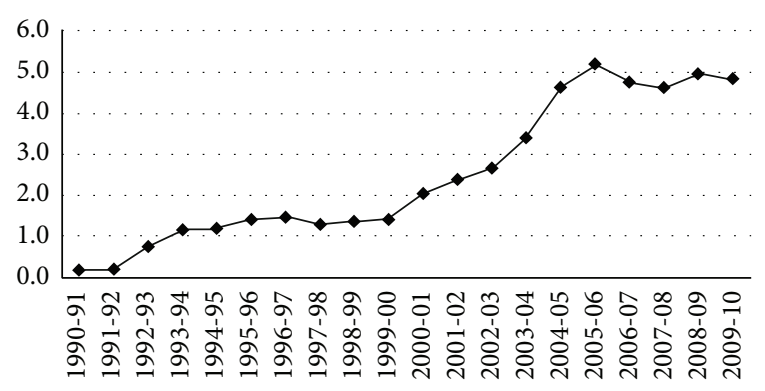

FIGURE 9: R \& D sales ratio in pharmaceutical industry in India (percentage). Source: Joseph [64].

process patent regimen the Indian drug companies manufactured the generic forms of the original patented drugs through another manufacturing process using reverse engineering. In the post-2005 process and product patent regimen the companies can manufacture generic forms only after the expiry of the original patent on the drug.) However, one argument that was vigorously pushed in the years immediately before shifting to the product patent regimen in 2005 was that the new patent regimen would propel the Indian drug manufacturers to spend more in R \& D and innovate.

Figure 9 shows the trends in the R \& D expenditures of Indian companies since the beginning of the 1990s. It can be seen that the R \& D to sales ratio did start increasing steadily since the beginning of the 1990s and peaked in 2004-2005, but thereafter it has declined rather than increasing as previously argued.

Just how narrow is the base of $\mathrm{R} \& \mathrm{D}$ is shown by the fact that the rise in $\mathrm{R} \& \mathrm{D}$ beginning 2000s was largely due to increased investments by just two companies-Dr Reddy's Laboratory and Ranbaxy. Post-2005 decline in the graph shown in Figure 9 is also due to the fact that these two companies decreased their spending consequent to failure of their new molecular innovations (in developing which they had made heavy investment) failing clinical development. The inability of the Indian companies to take up innovation can be attributed to that fact that neither do they have the support of a robust publically funded research domestically nor do they have the enormous financial muscle of their own to be able to compete with the multinational corporations in terms of their R \& D.

True to the comprador nature of the Indian bourgeoisie, the Indian drug companies are either concentrating on the development of the generics market [26] or are entering into various forms of contract research a junior partners to the multinational companies. Faced with changed circumstances after 2005 in the new patent regimen the owners of Ranbaxy thought it fit to sell out to pharma major Daiichi Sankyo of Japan in November 2008. Ranbaxy being the "India's largest drug firm and a technology bellwether" [65] was the one expected to lead India's drug innovation charge in the great battle of competitiveness. Writing of this abject surrender, Seth writes- "Of what use is Indian entrepreneurship if it cannot be sacrificed at the altar of avarice" [66]. 
Though contract research does provide a source of revenue for the Indian companies but it is doubtful if this can contribute to competence building due to the piecemeal nature of the work where there is never an exposure to the complete process of new drug development. These arrangements do not involve any technology transfer to the Indian companies; at best they may result in some skill development in the individual segments of drug development [64].

Among the various forms of collaborative research projects, the most common are the clinical trials which are the least knowledge intensive part of the new drug development. Further, most of the clinical R \& D activity of the MNCs is concentrated in phase 3 trials, which indicates that the global drug companies are far more interested in India's ability to provide a steady stream of patients rather than the competencies of its English speaking doctors, or the CROs or the network of its medical colleges [67].

While our policy planners may be happy projecting India's vast infrastructure of public hospitals, medical colleges, and research institutions to hard sell India as the destination of choice for conducting clinical trials, the unfortunate part is that the foreign companies are proving themselves to be far more adept at utilizing our infrastructure for their profits rather than India being able to put this infrastructure to best use for the welfare of India's impoverished masses [67]. The following example best illustrates this contention.

National Institute of Nutrition, Hyderabad, India, conducted a study titled "Effect of micronutrient supplement on health and nutritional status of schoolchildren: bone health and body composition," that was published in the Journal of the institute-"Nutrition" - in the year 2006 [68]. This study, supported by M/S Glaxo Smith Kline Consumer Healthcare Ltd. gave a micronutrient enriched beverage having the same composition as a nutritional supplement product of Glaxo Smith Kline that comes by the name of "Horlicks" [69]. Needless to say that the study proved all the virtues of the micronutrient enriched beverage (read "Horlicks") that the company desired to be proved.

In his capacity as the then medical editor working with a knowledge process outsourcing firm the author had the opportunity to attend the meeting of the "scientific advisory board" of the company that was convened to chalk out commercial promotion strategy for "Horlicks" at an exclusive Delhi hotel. In that meeting, the senior executive of the company who was in charge for the product while flashing the copy of the Journal "Nutrition" recounted the much rewarded tale of her involvement in the study conducted by NIN right from its conceptualization, to its design and actual conduct of the study. Among the luminaries present at the meeting were a leading pulmonologist from one of India's most reputed medical institutes, the head of pharmacology department of the same institute, a retired professor of pharmacology from a prestigious medical college of Delhi, a serving professor of the Institute of Tropical Medicine, Calcutta, and none other than the then director of "National Institute of Nutrition," Hyderabad, among others.

Whatever may be the expertise of a pulmonologist, or a pharmacologist, or an expert in tropical medicine in opining about child nutrition, one wonders if "Horlicks" can be proposed as a solution to the massive problem of malnutrition among children in India. The "National Institute of Nutrition" perhaps believes it is.

\section{Trial by the Whet Stone of Ethics}

Let it be reiterated here once again that to negate the importance of clinical trials in the development of new drugs and thereby in advancing research for new treatments for the immense human suffering on account of disease is certainly not the argument of this paper. And to this extent clinical trials are a sacrosanct tool in the service of humanity. The problem, however, arises when this tool is plied to serve vested interests and individual greed. Ethics is all about negating vested interests and individual greed.

Formally speaking the core principles of ethical decision making in medical practice are [70] the following.

(i) Autonomy. It means that "patients should be the ultimate decision-makers in matters that affect themselves" (World Medical Association). The practice of "informed consent" that obliges the researcher/doctor to provide all the necessary information to a patient to enable him/her to take an "informed" decision regarding his/her participation in the trial flows from the principle of autonomy.

(ii) Beneficence. Doctors ought to act in the best interests of their patients.

(iii) Nonmaleficence. Doctors/medical researchers ought not to bring any harm to patients/research subjects.

(iv) Justice. There should be a just allocation of medical resources. Various approaches to achieving this have been suggested-Libertarian, Utilitarian, Egalitarian, and Restorative.

Apart from these another ethical principle is "respect and dignity"-both the patient and the doctor ought to treat each other with mutual respect and dignity.

These principles are all very fine; the question, however, is how do we see them so very often turn into promises written on water? It is futile here to merely repeat the numerous examples which so convincingly demonstrate how these ethical principles have often been violated unless we can unravel the underlying reasons. And the reasons lie in the fact that the "de jure" principles have to operate in the given political, economic, and social conditions of the real world which dictate the "de facto" ethics of the society.

The most formidable ethical rationale favoring clinical trials is that it is an instrument of achieving collective wellbeing of human race in pursuit of alleviating human suffering caused by a number of diseases without by itself differentiating between divisions of caste, class, creed, race, or ethnicity. Most unfortunately, this tool for collective well-being has run into a political, economic, and social order that privileges individual or group interests over the collective. Economic interests of individual or a small group of countries, individual or a small group of corporations, a minority of dominant ethnic, racial, caste or class interests, or of professional groups have come to dominate the collective. The power that these 
individuals or groups wield over the collective dictates the practice of ethics irrespective of the professed principles of ethics.

The group of OECD countries powered their way down vanquishing the interests of the people of the developing world in the Uruguay round of GATT negotiations by forcing upon them an agreement on TRIPS and TRIMS (Trade Related Investment Measures) to upstage the economic interests of their corporations. The phenomena of clinical trials in the developing countries particularly owe to these measures. The following example not only brings out the power play between nations but also shows the extent to which drug industry is swayed by any kind of altruistic notions.

When South Africa, with almost 8 percent of its population afflicted with AIDS, passed the "Medicines and Related Substances Act" in 1997 to allow the local drug companies to manufacture generic forms of AIDS drugs patented by US corporations in order to reduce their price by up to 90 percent, the then US Vice President Al Gore led the "assiduous, concerted campaign" on behalf of US pharmaceutical industry to "persuade" the government of South Africa to change the law as it stood in infringement of the "patent regimen." Incidentally, US drug industry biggest representative body Phrma was a contributor to Gore's presidential campaign in 1999 [71].

The comprador ruling classes of India saw for themselves an economic opportunity in this and among various other policies began to project the working masses of India as "treatment naïve repositories of all kinds of diseases" to make India the preferred destination for clinical trials. Sections of drug industry, medical profession, and scientific community too let the economic interests get the better of them and we had a host of CROs and even independent (call commercial) ethics committees spring up within a matter of years. These are not charitable entities that have come to fill a crucial void in furtherance of "collective human well-being;" they are corporate entities out to make profit, of course with a veneer of science and societal good.

There is another side to this exclusivity too-in the number of controversies on clinical trials that have taken place in the country the victims have almost exclusively been the poor and the marginalized, a fair share of them being from the oppressed castes [72]. This is one reality that has remained unchanged since the 1932 Tuskegee trials on black syphilis patients in Macon County, Alabama, USA, the Guatemala syphilis experiment on prisoners by US doctors, 1946-1948, and the human experiments on prisoners by Nazi doctors. That Tuskegee is not an event of yore was once again proved in 2004- 05 by the AstraZeneca Plc sponsored trials to test its antipsychotic compound Seroquel XR wherein schizophrenic patients were given placebo. The multicentric trials took place on sites in India, Bulgaria, Poland, Russia, and the Ukraine [73].

Money, greed, subterfuge, coercion, official complacency, even complicity, and outright criminality all have been at play in giving rise to many sordid controversies surrounding clinical trials in the country. These are all available in public domain to be examined by those interested in knowing the details.
The question of ethics is not simply a technical question of making laws and setting up regulatory bodies/mechanisms; it is a question tied to larger politics that is driving developmental and economic policies. So long as pursuit of medical science shall be continued to be tied to profits, ethics and regulations shall continue to be undermined. Ingenious ways of doing so can be many. These days they even have Independent Ethics Committees that are available for commercial hiring by the CROs/Institutions/researchers whose ethics these Committees shall supervise-this is akin to the judge being paid by the under-trial to pass a fair judgment on the case. Else if one ethics committee fails a research project, one can always shop for another.

Even if the process of ethical review is ostensibly sincere, much is found lacking in the functioning of the ethics committees to ensure that the trials are conducted in a manner as to uphold the desired principles of ethics. The following findings of an M. Phil. dissertation from the Centre for Social Medicine and Community Health, Jawaharlal Nehru University, that examined the functioning of "Institutional Ethics Committees" (IECs) of six public and private hospitals from Delhi leave much to be desired [74].

(i) The major preoccupation of the ethics committees was with procedural requirements like informed consent and insurance coverage for the trial subjects, but there was little inclination towards fathoming the extremely complex terrain in which ethics actually operate which is reflected in the fact that none of the IECs that were studied actually made any field visits to actually monitor ongoing clinical trials.

(ii) The ethics committee members had little understanding of the "scope of applying ethical principles in safeguarding the rights and interests of human trial subjects." For example, safeguarding the interests of the clinical trial participants by suitably interpreting ethical guidelines and regulations and ensuring that the interests of the sponsors and the institutions did not conflict with those of the patients is the function of the legal fraternity member on IEC. However, in view of the Member Secretary of ethics committee of a public hospital, they had the lawyer on the committee to take care of the RTI applications, while the lawyer himself described ethics as "not my field. The doctors are the experts."

(iii) There was clear conflict of interests in the procedures followed for the investigation of a trial related death.

(iv) It was found that there were pressures exerted by the institution and demands from sponsors/investigators to expedite the process of ethical review. This could lead to IEC members ending up compromising their primary duty of ensuring the protection of human subjects.

(v) Most importantly, the IEC members failed to question the societal structural inequalities that underlie the decisions regarding the kind of clinical trials that are taking place in India today and their relevance to the public health needs of the country. 
With a view to systematizing the functioning of ethics committees recently the government passed the "The Drugs and Cosmetics (Third Amendment) Rules, 2013" to mandate for compulsory registration of independent ethics committees [75]. Though such steps are much required, however, given the overall scenario the spirit behind these remains perfunctory than substantive. As yet the clinical trials in India continue to be governed by regulations given in schedule Y of the "Drugs and Cosmetics Act, 1940," but these regulations specify only guidelines that are not legally enforceable. A draft bill on "Biomedical Research on Human Participants (Promotion and Regulation)" was prepared by the Indian Council of Medical Research (ICMR), but there has been little meaningful movement on that till now. The need is for such measures to be adopted after a wide ranging public discussion and debate involving all the stake holders [76].

\section{Typology of Indian Trials}

One would naturally expect that when so much is being said and done to promote clinical trials to find new solutions for different diseases, then they would at least be conducted to find new solutions to the major public health problems of the country. To examine this we did a search of the clinical trials registered with the "Clinical Trials Registry of India" (CTRI). There are a total of 906 trials registered with CTRI. Taking trials of all types of study designs, of all phases and recruitment status in all the states and districts, searching for trials by the key word "drugs" yielded a total of 453 trials registered with CTRI as on March 15, 2013.

The typology of 453 drug trials registered with CTRI was as given in Table 3. Additionally, we shall seek to analyze the typology of drug trials in Table 3 against the top 10 causes of mortality in India given in Table 4.

The following can be seen from Table 3.

(1) Nearly $2 / 3$ rd of the trials have been sponsored by private sponsors-drug companies, foreign institutions, or private Indian institutions/persons. Only about a third of the trials have been sponsored by public institutions. This again is a reflection on the commitment of the government to pitch in as a major sponsor for medical research in the country.

(2) More than 60 percent of the trials are either phase 3 or phase 4 trials. This only reaffirms that the clinical trials are coming to India majorly because of the patients it can supply rather than its technical expertise. This is not likely to result in comprehensive indigenous capability in new drug development.

(3) A very small proportion of the drug trials were concerning infectious diseases, just 8.6 percent overall. What is more worrisome is the fact that even in the publically sponsored trials the proportion concerning infectious diseases was lesser than that in privately sponsored clinical trials, that is, 8.5 percent.

Table 4 clearly shows that infectious diseases continue to be a major killer in India in different age groups and these are diseases which primarily affect the poor. In children diarrheal diseases are the foremost killer, yet overall only 0.7 percent of the trials concerned gastrointestinal infections, while among the publically sponsored trials not even one concerned diarrheal diseases. Likewise respiratory infections are a major killer among infants, yet only 1.1 percent overall and 0.7 percent of the publically sponsored trials were concerning respiratory infections. Tuberculosis, which is a major killer among adults, continues to be another neglected disease.

(4) A huge proportion of clinical trials is concerning rarer indications covered under "all other conditions." The proportion under this category is higher for publically sponsored trials than the overall figure or in privately sponsored trials. This phenomenon regarding clinical trials is well recognized in the literature. It has been observed that only 10 percent of the research on drugs actually concerns diseases that constitute 90 percent of the disease burden [77].

\section{Conclusion}

Without being cynical we would like to end by what we began with that clinical trials are an important tool to further human well-being in the process of finding new solutions to the diseases and health problems afflicting humanity. However, the application and practice of this tool stands greatly distorted due to its subjugation to profit motive of the pharmaceutical multinationals rather than to further its primary motive. It is wrong to assert that human well-being function of clinical trials can only be achieved if there are adequate monetary incentives built in for the researchers and the drug manufacturers for we have seen that such a system has singularly undermined the interests of the patients. Additionally, there is a need to recognize the power relationships that operate between countries, within countries between different social classes, and between the physicians and patients which have defined the manner in which clinical trials industry has grown in the developing world. These power relationships undermine all the regulations that may be put in place to ensure ethical conduct of clinical trials.

The solution clearly lies in freeing clinical trials from its subservient role to generating profits for the healthcare industry. This requires that the Indian government pull India out of the TRIPS agreement and replace it with a patent regimen that is designed not merely to fulfill our narrow national interests but throws a challenge to the model of knowledge generation, its appropriation, and utilization as imposed by the developed countries of the world in defense of the interests of the impoverished masses across the world. Fundamental to such an attempt would be to build a robust network of public institutions for carrying out biomedical research in tune with the public health needs of the country. This should be adequately utilized by an equally robust network of manufacturing facilities in the public sector as also the required support to the private sector to prevent it from capitulating to the might of the multinationals from the developed world. India should make attempts to share the knowledge/technology generated in its labs with other developing countries on liberal terms. 
TABLE 3: Typology of drug trials registered with CTRI.

(a) Categorization by type of sponsor

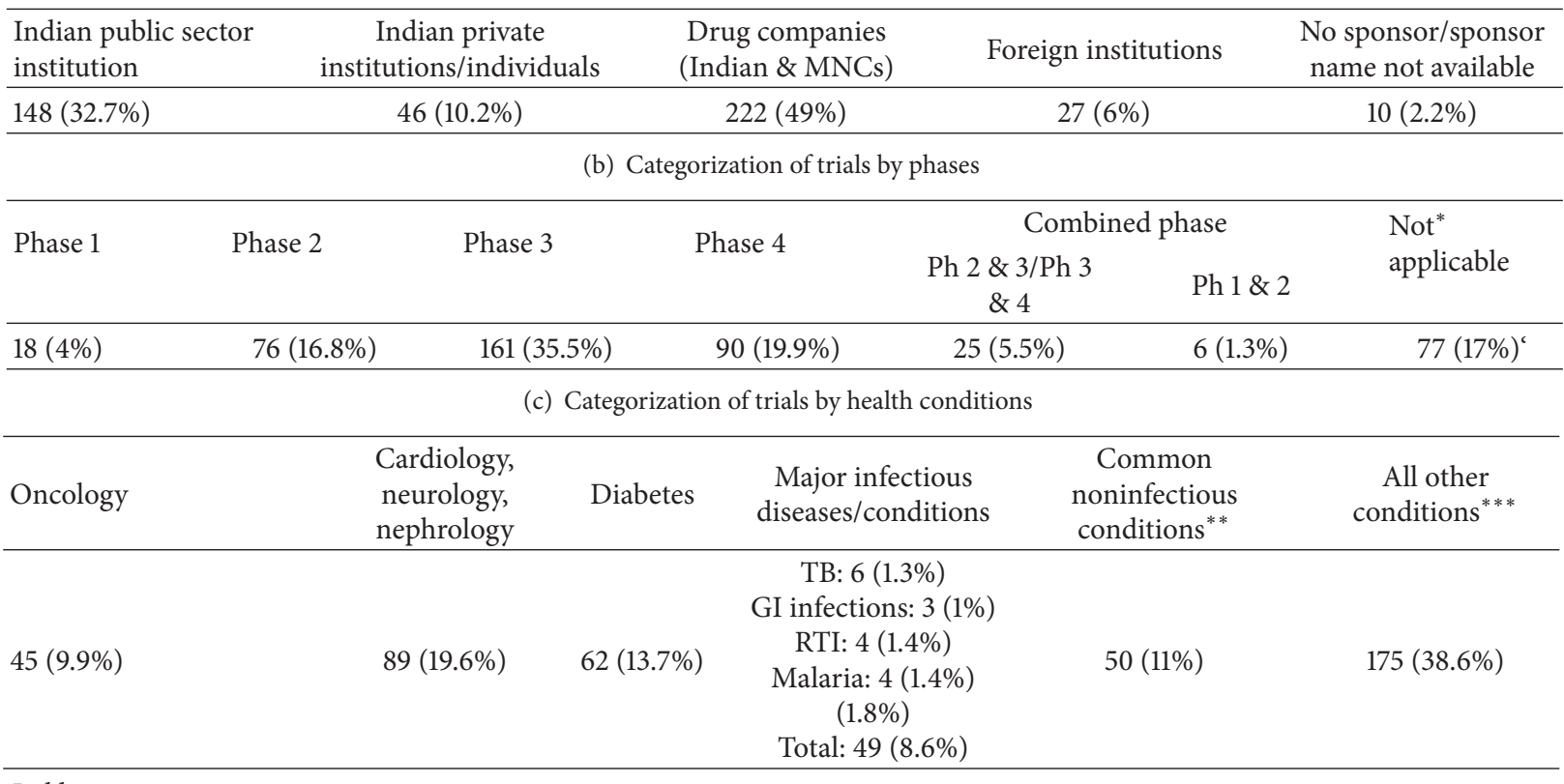

Public sector sponsor

TB: $3(2 \%)$

$6(4 \%) \quad 30(20.3 \%) \quad 14(9.5 \%)$

GI infections: $0(0 \%)$

RTI: $1(.7 \%)$

Malaria: $4(2.7 \%)$

Total: $10(6.8 \%)$

Private sector sponsor

TB: $2(.7 \%)$

$38(12.9 \%) \quad 60(20.4 \%) \quad 48(16.3 \%)$

GI infections: $3(1 \%)$

RTI: 4 (1.4\%)

Malaria: $4(1.4 \%)$

Total: $10(6.8 \%)$

${ }^{*}$ These were trials that were trying to establish clinical usage of a drug for some indications, forexample, in case of ayurvedic drugs, or were exploring new indications for drugs already in usage for other conditions. ${ }^{* *}$ These included painful conditions (acute and chronic asthma, dyspepsia, indigestion, conjunctivitis, sore throat, common skin conditions, reproductive tract infections, depression, etc.). ${ }^{* * *}$ These included drugs used for all the other indications not covered by earlier categories.

TABle 4: Tope 10 causes of death in India (ages: <1 yr, 1-4 yrs, and 25 to $69 \mathrm{yrs}$ as \%), 2001-2003, all India.

\begin{tabular}{lll}
\hline$<1$ year (infants) & 1 to 4 yrs & 25 to 69 yrs \\
\hline (i) Perinatal conditions (46\%) & (i) Diarrheal diseases (24\%) & (i) Cardiovascular diseases (25\%) \\
(ii) Respiratory infections (22\%) & (ii) Respiratory infections (23\%) & (ii) COPD, asthma, other respiratory (10.2\%) \\
(iii) Diarrheal diseases (10\%) & (iii) Other infectious and parasitic & (iii) Tuberculosis (10.1\%) \\
(iv) Other infectious and parasitic & diseases (16\%) & (iv) Malignant and other neoplasms (9\%) \\
diseases (8\%) & (iv) Unintentional injuries: other (8\%) & (v) Symptoms signs and ill-defined \\
(v) Congenital anomalies (3.1\%) & (v) Malaria (7\%) & conditions (5.3\%) \\
(vi) Symptoms, signs and ill-defined & (vi) Nutritional deficiencies (4.8\%) & (vi) Digestive diseases (5.1\%) \\
conditions (3\%), & (viii) Symptoms, signs and ill-defined & (vii) Diarrhoeal diseases (5\%) \\
(vii) Nutritional deficiencies (2\%) & conditions (4.5\%) & (vii) Unintentional injuries: Other (4.6\%) \\
(viii) Unintentional injuries: other (1.4\%) & (ix) Fever of unknown origin (3\%) & (ix) Intentional self-harm or suicide (3\%) \\
(ix) Malaria (1.1\%) & (x) Digestive Diseases (1.7\%) & (x) Malaria (2.8\%) \\
(x) Fever of unknown origin (0.9\%) & (xi) Congenital anomalies (1.5\%) &
\end{tabular}

Source: Registrar General of India, 2009 [78]. 
India has the capacity to do all of this; the point, however, is that are the comprador ruling classes of the country willing to undertake all of this? We fear that this is not yet. India's scientific community ought to rise to the occasion in enlightening the people about the alternatives.

\section{References}

[1] S. Nundy and C. M. Gulhati, "A new colonialism? - conducting clinical trials in India," The New England Journal of Medicine, vol. 352, no. 16, pp. 1633-1636, 2005.

[2] P. Bagla, "Clinical research. India acts on flawed cancer drug trials," Science, vol. 293, no. 5539, pp. 2371-2373, 2001.

[3] G. Mudur, "Indian study sparks debate on the use of placebo in psychiatry trials," British Medical Journal, vol. 332, no. 7541, article 566, 2006.

[4] A. Sengupta, "Fatal trials: clinical trials are killing people," Inidan Journal of Medical Ethics, no. 3, pp. 118-119, 2009.

[5] P. Shetty, "Vaccine trial's ethics criticized," Nature, vol. 474, pp. 427-428, 2011.

[6] T. K. Rajalakshmi, "Criminal trials," The Frontline, vol. 29, no. 2 , 2012.

[7] FICCI (Federation of Indian Chambers of Commerce and Industry), "Global clinical trials in India: prospects and challenges," in Proceedings of the Bio-Business Summit 2005, White Paper, New Delhi, India, November 2005.

[8] Indian Council for Research on International Economic Relations (ICRIER), "Health research: its potential in India," in India Health Report, R. Misra, R. Chatterjee, and S. Rao, Eds., pp. 188196, Oxford University Press, New Delhi, India, 2003.

[9] R. Maiti and M. Raghavendra, "Clinical trials in India," Pharmacological Research, vol. 56, pp. 1-10, 2007.

[10] S. Drabu, A. Gupta, and A. Bhadauria, "Emerging trends in contract research industry in India," Contemporary Clinical Trials, vol. 31, no. 5, pp. 419-422, 2010.

[11] J. Joseph, "Entering the contract research industry in India," Contemporary Clinical Trials, vol. 29, no. 3, pp. 311-313, 2008.

[12] Y. K. Gupta and B. M. Padhy, "India's growing participation in global clinical trials," Trends in Pharmacological Sciences, vol. 32, no. 6, pp. 327-329, 2011.

[13] U. S. Department of Health and Human Services, "What are clinical trials?" 2012, http://www.nhlbi.nih.gov/health/healthtopics/topics/clinicaltrials/.

[14] M. Angell, "The creation of a new drug," in The Truth About the Drug Companies, p. 30, The Random House, New York, NY, USA, 2005.

[15] T. Ross, "An Overview of the Drug Development Process," May-June 2005, The Physician Executive, p 48-52, http://www .google.co.in $/ u r l$ ? $s a=t \& r c t=j \& q=\&$ esrc $=s \&$ frm $=1 \&$ source $=$ web\&cd $=1 \& c a d=$ rja\&ved $=0$ CDsQFjAA\&url=http $\% 3 \mathrm{~A} \% 2 \mathrm{~F} \%$ 2Fnet.acpe.org\%2FResources\%2FArticles\%2FDrug_Development.pdf\&ei=nQs-UYroEoiSrgfl2YHQDA\&usg=AFQjCNFxMwxlJe8KLFmJUcqvgFtEyX4uIQ\&bvm=bv.43287494,d.bmk.

[16] M. Angell, “The creation of a new drug," in The Truth About the Drug Companies, pp. 21-36, The Random House, New York, NY, USA, 2005.

[17] Department of Health and Human Services, Office of Inspector General, "Recruiting human subjects: pressures in industrysponsored clinical research," Tech. Rep. IWU-01-97-00195, p. 17, Department of Health and Human Services, Office of Inspector General, Washington, DC, USA, 2000.
[18] S. Tim, “People keep falling sick': how poor Indians are recruited for clinical drug trials," March 2013, NBCNews.com, http://openchannel.nbcnews.com/_news/2012/03/02/10561824people-keep-falling-sick-how-poor-indians-are-recruited-forclinical-drug-trials?lite.

[19] UNCTAD, UNCTAD Survey on the Internationalization of R\&D Current Patterns and Prospects on the Internationalization of R\&D, United Nations, New York, NY, USA, 2005.

[20] IBM Global Business Services, "Global location trends," Annual Report, p. 8, IBM Global Business Services, London, UK, 2010.

[21] S. Mishra, "Clinical Trial Industry in India-A Progress Story," US India Business Council (Undated), http://www.usibc .com/sites/default/files/members/files/ficcidrsmishraaiims.pdf.

[22] "Destination India: Contract Research in Pharmaceuticals \& Healthcare," talk given by the Chairperson, Association of Contract Research Organizations, S. P. Vasireddy, New Delhi, India, mentioned in "Quality News", newsletter of the Confederation of Indian Industries, February-March 2009, http://newsletters.cii.in/newsletters/quality_news/iq_February_ March09/pdf/quality_news09.pdf.

[23] WTO, “Overview: the TRIPS agreement," 2013, http://www.wto .org/english/tratop_e/trips_e/intel2_e.htm.

[24] WTO, "Uruguay round agreement: TRIPS—part II—standards concerning the availability, scope and use of intellectual property rights," 2013, http://www.wto.org/english/docs_e/ legal_e/27-trips_04c_e.htm\#Footnote8.

[25] WTO, "Least developed countries' priority needs in intellectual property," 2013, http://www.wto.org/english/tratop_e/trips_ e/ldc_e.htm.

[26] A. Satish, "The productivity tiger-time and cost benefits of clinical drug development in India," February 2013, http://pharmalicensing.com/public/articles/view/1153412098_44bfac02291f1.

[27] S. Nundy, M. Chir, and C. M. Gulati, "A new colonialism?conducting clinical trials in India," The New England Journal of Medicine, vol. 352, no. 16, pp. 1633-1636, 2005.

[28] S. Sandhya, Ethical Concerns in Clinical Trials in India: An Investigation, Centre for Studies in Ethics and Rights, Mumbai, India, 2009.

[29] S. Singh, "Clinical Trials New Horizon-India," February 2013, http://www.who.int/medicines/areas/quality_safety/regulation_ legislation/icdra/1_India_ClinicalTrialsNewHorizon.pdf.

[30] OIG, The Food and Drug Administration's Oversight of Clinical Trials, Department of Health and Human Services, Government of United States, Washington, DC, USA, 2007.

[31] Union of Concerned Scientists, "Industry influence on drug and medical device safety at FDA $-\$ 700$ million in lobbying buys significant access," March 2012, http://www.ucsusa.org/assets/documents/scientific_integrity/industry-influence-drugmedical-device-safety-FDA.pdf.

[32] D. M. Solet and P. B. Hutt, "Strategies of Influence: How Corporate Power Directs and Constrains the FDA," May 2001, Howard Law School, http://leda.law.harvard.edu/leda/data/413/ Solet.html.

[33] S. W. Glickman, J. G. McHutchinson, and E. D. Peterson, "Ethical and scientific implications of the globalization of clinical research," The New England Journal of Medicine, vol. 360, no. 8, pp. 816-823, 2009.

[34] M. Sonal, "Parliament committee indicts drugs regulatory authority," May 2010, Down to Earth, http://www.downtoearth .org.in/content/parliament-committee-indicts-drug-regulatory-authority. 
[35] R. Smith, "Medical journals are an extension of the marketing arm of pharmaceutical companies," PLoS Medicine, vol. 2, no. 5, Article ID e138, 2005.

[36] J. Lexchin, L. A. Bero, B. Djulbegovic, and O. Clark, "Pharmaceutical industry sponsorship and research outcome and quality," British Medical Journal, vol. 3268, no. 4, pp. 1167-1170, 2003.

[37] A. D. Bhatt, “Clinical trial publications," Indian Journal of Medical Ethics, vol. 8, no. 4, pp. 119-121, 2000.

[38] S. Amit, "Research on hire," Indian Journal of Medical Ethics, vol. 9, no. 4, 2001.

[39] The Hindu, "ICMR okays stem cell research by AIIMS," April 2005, http://www.hindu.com/2005/04/06/stories/2005040612771300.htm.

[40] S. Srinivasan, "Rogue research in the guise of stem cell therapy," March 2006, Infochange Public Health, http://www.infochangeindia.org/public-health/features/rogue-research-in-theguise-of-stem-cell-therapy.html.

[41] K. S. Jayaraman, "Indian regulations fail to monitor growing stem-cell use in clinics," Nature, vol. 434, article 259, 2005.

[42] D. C. Sharma, "Johns Hopkins and RCC face drug trial allegations," The Lancet Oncology, vol. 2, no. 9, article 530, 2001.

[43] P. Bagla, "Despite note that AIDS vaccine had failed, India changed rules and continued trials," December 2007, The Indian Express, http://www.indianexpress.com/news/despite-note-thataids-vaccine-had-failed-india-changed-rules-and-continuedtrials/253329.

[44] S. K. Pandya, "Stem cell transplantation in India: tall claims, questionable ethics," Indian journal of medical ethics, vol. 5, no. 1, pp. 15-17, 2008.

[45] A. Naomi, "Tufts Center Estimates Amount up Threefold From a Decade Ago," December 2001, The Boston Globe, HighBeam Research, http://www.highbeam.com/doc/1P2-8686533.html.

[46] Public Citizen's Congress Watch, Rx R\&D Myths: The Case against the Drug Industry's R\&D 'Scare Card', Public Citizen, Washington, DC, USA, 2001.

[47] USA Families, "Profiting from pain: where prescription drug dollars go," Families USA Report 02-105, Families USA Foundation, Washington, DC, USA.

[48] A. A. Toole, "The impact of public basic research on industrial innovation: evidence from the pharmaceutical industry," Discussion Paper 11-063, ZEW-Centre for European Economic Research, Mannheim, Germany, 2011.

[49] W. H. Schacht, "The Bayh-Dole Act: issues in patent policy and the commercialization of technology," Tech. Rep. RL32076, Congressional Research Service, Washington, DC, USA, 2012.

[50] J. F. Sargent Jr., "Federal research and development funding: FY2013,” Tech. Rep. R42410, p. 5, Congressional Research Service, Washington, DC, USA, 2012.

[51] S. Chaudhuri, "R\&D for Development of New Drugs for Neglected Diseases: How Can India Contribute? Study prepared for WHO Commission on Intellectual Property Rights, Innovation and Public Health," 2005, http://www.who.int/intellectualproperty/studies/S.\%20Chaudhuri.pdf.

[52] M. Angell, “The $\$ 200$ billion colossus," in The Truth About the Drug Companies, pp. 6-9, The Random House, New York, NY, USA, 2005.

[53] R. Rhines, "Consequences of the Bayh-Dole Act," December 2005, MIT OPEN COURSEWARE, Massachusettes Institute of Technology, http://ocw.mit.edu/courses/electrical-engineering-and-computer-science/6-901-inventions-and-patents-fall2005/projects/bayh_dole.pdf.
[54] T. Riley and J. DeRuitere, New Drug Review, U.S. Pharmacist, Lyndhurst, NJ, USA, 2004.

[55] J. B. Graham, Trends in US regulatory approvals of biopharmaceutical therapeutic entities [Master in Science thesis], Massachusetts Institute of Technology, Cambridge, Mass, USA, 2005.

[56] M. Jonathan, "Lowering prescription drug prices in United States: are reimportation and internet pharmacies the Answer?" Southern California Interdisciplinary Law Journal, vol. 15, no. 345, pp. 345-375, 2006.

[57] D. L. Barlett, J. B. Steele, L. Karmatz, B. Kiviat, and J. Evinstein, "Why Drugs Cost So Much/The Issues '04: Why We Pay So Much for Drugs," 2004 February, Time Magazine, http://www .time.com/time/printout/0,8816,993223,00.html.

[58] W. L. Donald and R. L. Joel, "Pharmaceutical research and development: what do we get for all that money?" British Medical Journal, vol. 345, article e4348, 2012.

[59] A. D. So, B. N. Sampat, A. K. Rai et al., "Is Bbayh-Dole good for developing countries? Lessons from the us experience," PLoS Biology, vol. 6, no. 10, pp. 2078-2084, 2008.

[60] N. Kumar and N. Asheulova, "Comparative analysis of scientific output of BRIC countries," Annals of Library and Information Studies, vol. 58, no. 3, pp. 228-236, 2011.

[61] The Hindu, "Boosting Research in India," January 2012, Editorial in "The Hindu", http://www.thehindu.com/opinion/editorial/boosting-research-in-india/article2785862.ece.

[62] G. Abantika, "PM seeks to raise private sector funding in R\&D to $50 \%$," September 2011, Times of India, http://articles.timesofindia.indiatimes.com/2011-09-07/india/30122670_1_privatesector-pension-scheme-finance-ministry.

[63] Moneylife, "The Indian pharmaceutical saga: strong on generics, weak in R\&D," November 2009, http://www.moneylife.in/ article/the-indian-pharmaceutical-saga-strong-on-genericsweak-in-rd/2257.html.

[64] R. K. Joseph, "The R\&D scenario in Indian pharmaceutical industry," Discussion Paper \# 176, Research Information System for Developing Countries, New Delhi, India, 2011.

[65] P. P. Chaudhary, "The great ranbaxy sell-out: two diagnostic reports," June 2008, Hindustan Times, http://www.hindustantimes.com/editorial-views-on/Edits/The-great-ranbaxy-sellout-two-diagnostic-reports/Articlel-317538.aspx.

[66] S. Seth, "The great ranbaxy sell-out: two diagnostic reports," June 2008, Hindustan Times, http://www.hindustantimes.com/ editorial-views-on/Edits/The-great-ranbaxy-sell-out-two-diagnostic-reports/Articlel-317538.aspx.

[67] A. Dinesh, P. Prajapati, and N. Singh, "Globalization of the indian pharmaceutical industry: implications for innovation," International Journal of Institutions and Economies, vol. 3, no. 2, pp. 327-365, 2011.

[68] V. Shatrugna, N. Balakrishna, and K. Krishnaswamy, "Effect of micronutrient supplement on health and nutritional status of schoolchildren: bone health and body composition," Nutrition, vol. 22, supplement 1, pp. S33-S39, 2006.

[69] Glaxo Smith Kline (GSK) Consumer Healthcare, "Horlicks: The Great Family Nourisher," 2005, http://www.gsk-ch.in/horlicks_ninja.aspx.

[70] World Medical Association (WMA), Medical Ethics Manual, World Medical Association, Washington, DC, USA, 2nd edition, 2009.

[71] B. Julian, "Gore accused of working against cheap Aids drugs," August 1999, The Guardian, http://www.guardian.co.uk/world/ 1999/aug/10/uselections2000.usa. 
[72] S. L. Roberts, "Have India’s poor become human guinea pigs," November 2012, News Magazine, BBC, http://www.bbc.co.uk/ news/magazine-20136654.

[73] S. Irene and W. Francis, Ethics for Drug Testing in Low and Middle Income Countries: Considerations for European Market Authorization, SOMO (Centre for Research on Multinational Corporations), Amsterdam, The Netherland, 2008.

[74] K. Rohini, The role of institutional ethics committees in clinical trials: a study of selected hospitals in New Delhi [M Phil dissertation], Centre for Social Medicine and Community Health, Jawaharlal Nehru University, New Delhi, India, 2011.

[75] Gazette of India, The Drugs and Cosmetics (Third Amendment) Rules, 2013, Ministry of Health and Family Welfare, Government of India, New Delhi, India, 2013.

[76] A. Bhan, "Clinical trial ethics in India: one step forward, two steps back," Journal of Pharmacology and Pharmacotherapeutics, vol. 3, no. 2, pp. 95-97, 2012.

[77] A. Petryna, When Experiments Travel: Clinical Trials and the Global Search for Human Subjects, Princeton University Press, Princeton, NJ, USA, 2009, http://press.princeton.edu/chapters/i8916.html.

[78] Registrar General, India, Report on Causes of Death: 2001-03, Ministry of Home Affairs, New Delhi, India, 2009. 


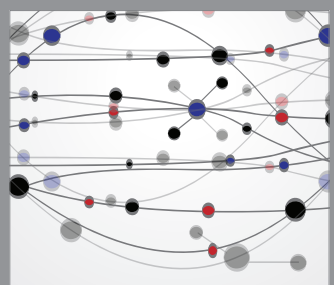

The Scientific World Journal
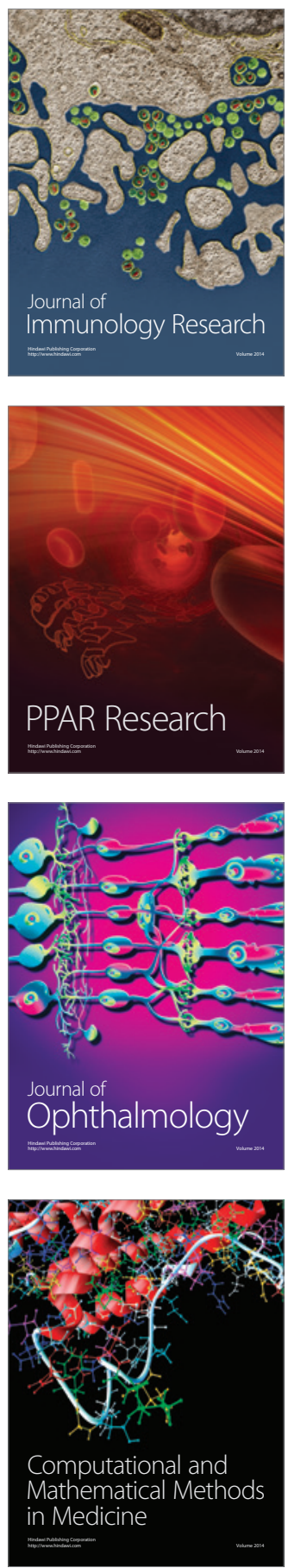

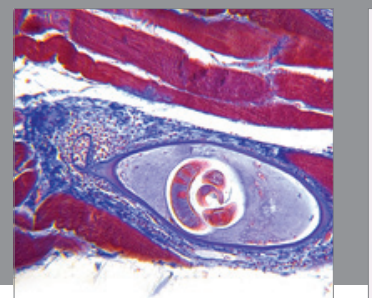

Gastroenterology

Research and Practice
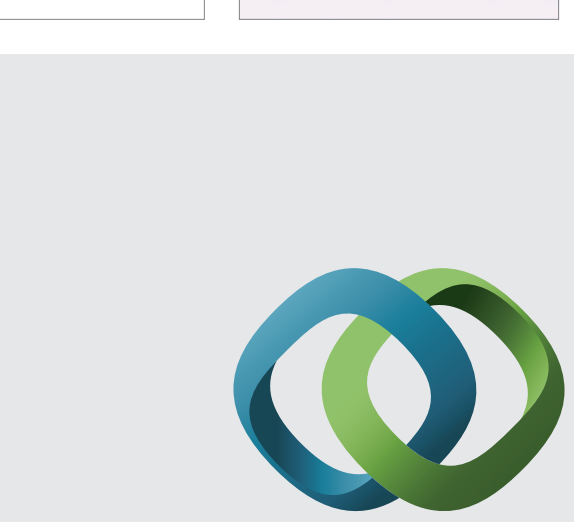

\section{Hindawi}

Submit your manuscripts at

http://www.hindawi.com
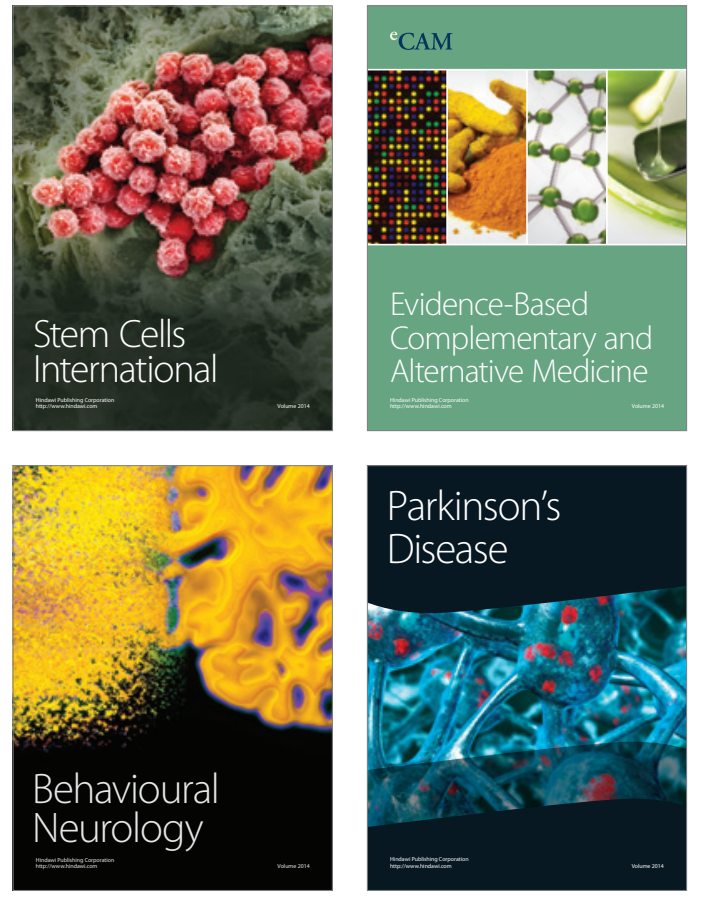
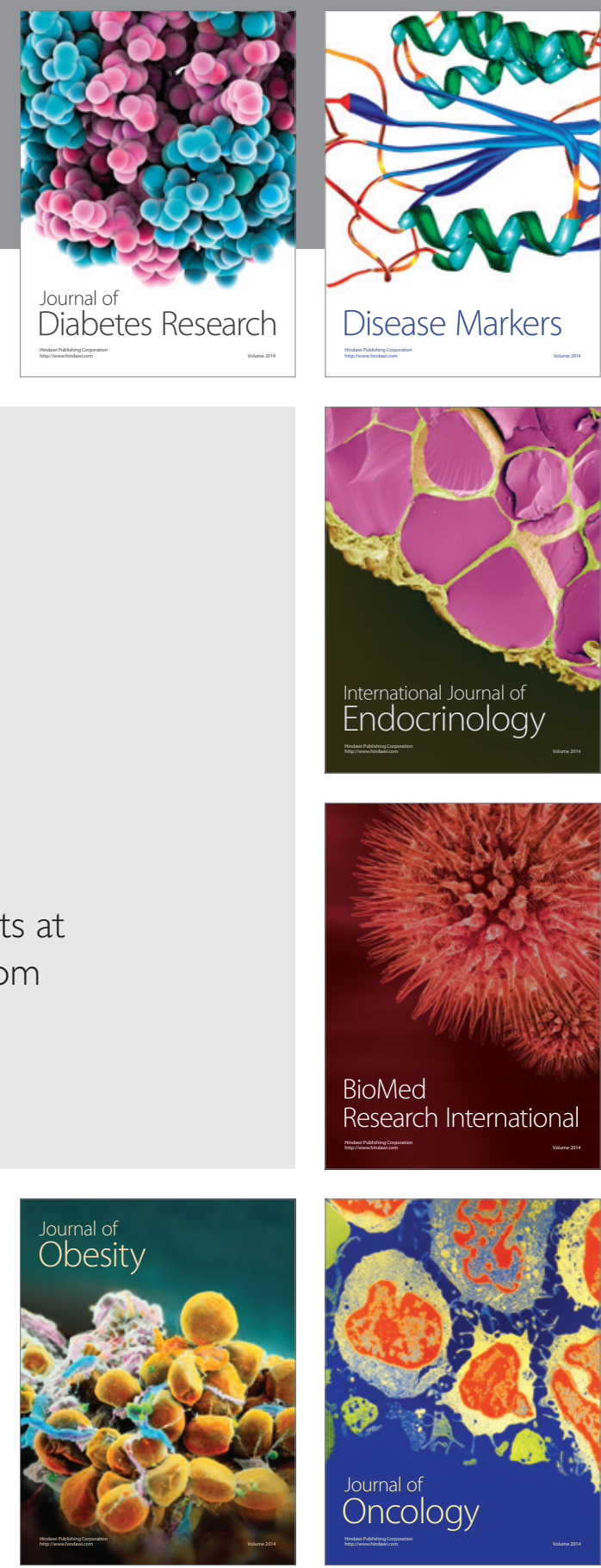

Disease Markers
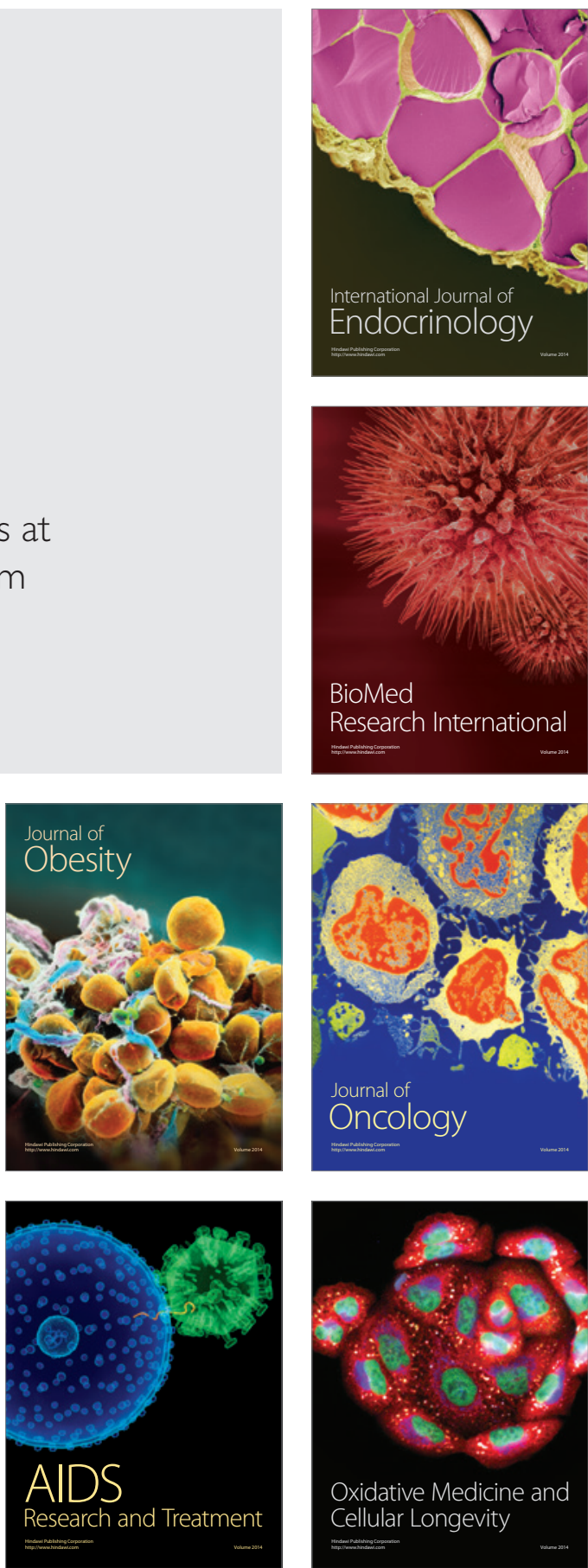